\title{
Shipwrecks with Baetican cargo in the Western Mediterranean, First to Third Centuries AD: maritime trade and cargo composition
}

\section{Stella Rendina}

Email: rendina.stella@gmail.com

\begin{abstract}
This paper examines the shipwrecks with Baetican cargo in the Western Mediterranean between the beginning of the $1_{\text {st }}$ century $\mathrm{AD}$ and the end of the 3 rd century $\mathrm{AD}$. It focuses mainly on cargo composed of amphorae-borne products and metal ingots, and the type of trade that wrecks with such cargo could represent. By looking at these wrecks as a coherent set and analysing the different cargoes, this paper outlines the mechanisms of trade of Baetican cargo and its underlining patterns. The end goal is to better understand the export economy of Roman Baetica in the first three centuries AD.
\end{abstract}

Key words

Maritime Archaeology, Shipwrecks, Baetica, Cargo, Roman Trade

\section{Introduction}

This paper is part of a wider study that examined the shipwrecks with Baetican (referring to Baetica, a Roman province in southern Spain that roughly corresponds to modern day Andalucía) cargo in the western Mediterranean between the 1 st and the 3 rd centuries AD as part of a master's thesis conducted 
at the University of Cadiz in 2019. Despite some limitations due to the nature of the materials that survive underwater, wrecks have the potential to outline the mechanisms through which products were transported, the ways in which they were loaded on a vessel, and how these products were combined in a hull. Ever since the publication of Parker's catalogue of wrecks which coherently listed 1,259 underwater sites, along with their location, their date, and the material recorded in each of them (Parker, 1992), wrecks have been fundamental in the study of the ancient economy.

Although extensive publications of shipwrecks with Baetican cargo are available, these wrecks have mostly been considered individually or, when considered together, scholars concentrated on specific locations, specific products, or produced a simple list of parts of the wrecks. Liou attempted to collect all of these wrecks together in an article published in 2000 (Liou, 2000), but his article tends to list wrecks with Baetican cargo without providing a conclusion or an analysis of the published material, and his focus is not on the organisation of the cargo but rather on the different wrecks and their location. In addition, his time span extends from the Republican period to the 5th century AD. Étienne and Mayet made a more complete analysis in their four volumes on Hispanic products (Etienne and Mayet, 2000, 2002, 2004). The authors focus on the different Hispanic products but analysed Baetican shipwrecks together with the ones from Lusitania and Tarraconensis, assessing the different products—oil, fish sauce, and wines - and the variety of producers more than the trade patterns these wrecks represented. Since cargo analysis has the potential of elucidating the different mechanisms of trade, the aim of my thesis was instead to discuss these wrecks together in a holistic comparative framework, undertaking a comprehensive analysis of their components. By considering the different cargo compositions, the locations of the wrecks, and the date and nature of the products transported, the aim of this paper is to attempt to understand the mechanisms of trade for Baetican cargo and their underlying patterns.

\section{Baetican products and trade}

We know that Baetican products played a fundamental role in the supply of the empire and especially in supplying Rome and the frontier zones of Germania and Britannia (Dressel, 1878; Carreras and Funari, 2000; Blázquez Martínez and Rodríguez, 2001; Remesal Rodríguez, 2002; Lagóstena Barrios, 2009; Remesal Rodríguez, 2010). Land excavations support this, as material evidence for this trade is visible in the three provinces. Shipwrecks, instead, show us the products that did not reach their destination and are snapshots of the ways in which these products travelled and how they were loaded on a vessel.

Despite this study focusing on a narrow selection of products, we know from Strabo that a much wider array of products was exported from Baetica, called Turdetania as it was the pre-Roman name of the area around the Guadalquivir river. 
There are exported from Turdetania large quantities of grain and wine, and also olive oil, not only in large quantities, but also of best quality. And further, wax, honey, and pitch are exported from there, and large quantities of kermes 1 , and ruddlez which is not inferior to the Sinopean earth. And they build their ships there out of native timber; and they have salt quarries in their country, and not a few streams of salt water; and not unimportant, either, is the fish-salting industry that is carried on, not only from this country, but also from the rest of the seaboard outside the Pillars; and the product is not inferior to that of the Pontus. Formerly much cloth came from Turdetania, but now, wool, rather of the raven-black sort... Turdetania also has a great abundance of cattle of all kinds... (Strabo 3, 2, 6, quoted in Jones, H. L., and Sitlington Sterrett, J. R., 1917)

Strabo's words are fundamental as they underline the limitation of the shipwreck data, which reveal information about a limited range of products and preserve no trace of perishable materials. This study is therefore limited to products that survive underwater, excluding grain, wax, pitch, cloth, and honey, which we know were being transported thanks to Strabo's words; and if available in the archaeological record, such evidence would provide a whole different set of information. Further limitations must also be kept in mind while looking at shipwrecks: most of the wrecks studied have only been partly excavated or published, and some had also been looted. Further, the movement of water displaced many of the amphorae and they are often found distant from their original location, when they are not simply lost, leading to a loss of information.

The variety of products that were being shipped and loaded on vessels departing from Baetica often resulted in very heterogeneous cargoes, which were loaded at only one harbour and must therefore not be thought of as the result of cabotage. The model of direct trade through emporia is the primary mode of trade during the Roman period (Nieto, 1997; Wilson, 2011; Rice, 2016). This model implies a level of planning and organisation, based on the available information about markets. The evidence provided from the Baetican shipwrecks with heterogeneous cargo implies that these ships were loaded in a single harbour, an emporium, where the products were being collected, stored, and loaded together on a vessel, not due to a random exchange and loading.

\footnotetext{
${ }^{1}$ A crimson dye-stuff obtained from the dried body of insects.

2 Used by Strabo to refer to Spanish cinnabar and Sinopean "red earth" as sources of dyes.
} 


\section{Wrecks with Baetican cargo}

This study collected data about 91 different wrecks from across the western Mediterranean (Table 1). Some wrecks were better published than others and have allowed for a complete analysis of the cargo, while others, only partly excavated, might have had more cargo than is reported here. The aim has been to collect all this information in one location to view these wrecks as a coherent set, and answer a series of questions:

- What can these wrecks tell us about Baetican maritime trade and its underlying mechanisms?

- Which Baetican products were commonly transported together?

- From which province(s) did products travelling alongside Baetican cargo come from?

\section{Map and location}

Figure 1 shows the location of all of the wrecks considered in this study. We can see where most of the wrecks have sunk, especially near dangerous navigational spots (such as the Balearic islands and the strait of Bonifacio), and perhaps the routes of the vessels. The graph in Figure 2 plots the number of wrecks found in Spain, France, and Italy. This distribution is not representative of the totality of Baetican trade, but is rather an artefact of different environmental contexts that encourage or prohibit documentation, as well as the different levels of research investment of each country.

The map reveals an absence of shipwrecks on the Italian coast near Rome. This could be due to the sandy sea bed, which makes wrecks difficult to locate, or to the high availability of harbours on this coast that would have provided shelter in case of bad weather (Robinson et al. Forthcoming, Schörle, 2011), or to a combination of both factors. There is a high concentration of wrecks on the French coast, probably tied to both a high investment in underwater research and the type of seabed that results in a better visibility of wrecks. No wrecks were recorded on the North African coast because of the lack of systematic research.

\section{Chronology of the wrecks}

Figure 3 plots the probable dates of the wreckage of these 91 Baetican cargo shipwrecks (Figure 3). Following Andrew Wilson's probability per annum approach (Wilson, 2009, 2011), the probability that each wreck sunk in a specific year of its date range was calculated and then plotted in a graph subdivided by half century. The first and last columns contain only the wrecks dated outside the set time span, for example a wreck dated $25 \mathrm{BC}-25 \mathrm{AD}$ do not represent the complete set of wrecks with 
Baetican cargo sunk in these two time frames, as many more wrecks with a Republican or late imperial date are available and not classified here.

From Figure 3, we see that $60 \%$ of all the wrecks sank in the 1 st century AD, while there is a decline in the second century. This contrasts with the terrestrial evidence, especially from Monte Testaccio and the area around Rome, where we see a continuation of Baetican imports in amphorae up until the 4th century AD. What we can hypothesize is that this decline in the number of shipwrecks could be due to a change in the trade routes, shifting from coastal to high sea, to a better knowledge of the sea conditions and of hazardous locations, to the use of larger ships with better sailing capacities that were less prone to sinking, and to a larger number of harbour structures and lighthouses in the second century AD (Blackman, 2008; Harris et al., 2011; Oleson et al., 2011). Furthermore, as discussed by Robinson, Rice, and Schörle (forthcoming), the investment in new harbour structures and lighthouses that started in the 1 st century AD provided shelter, visible markers, and safe havens at regular intervals on both the Italian Tyrrhenian coast and the southern French coast (Robinson et al, forthcoming). While the high number of wrecks in the 1 st century AD could be tied to the change of politics that occurred with Augustus's accession to the throne, the end of piracy, and the opening of the sea that must have incentivized smaller scale traders in investing in sea trade with smaller vessels due to the profit this promised.

\section{Origin of the cargo}

By looking at the origin of the cargo in these Baetican shipwrecks, a series of different combinations are available. Even though Baetican products were at times transported alongside products from other provinces, the majority of the ships (77 out of 91) were carrying exclusively Baetican products (Figure 4). The 14 remaining ships that carried cargoes from mixed provinces do not seem to be part of a pattern, and are single examples of combinations between provinces which seem to represent individual cases.

The 77 wrecks with exclusively Baetican products can be understood as representing the first major journey of these products departing from Baetica. An initial stage of transport would have involved a short journey by river, land, or sea to reach the main emporia in which they were then loaded together on these bigger vessels that then wrecked. While these cargoes were in the initial stage of their transport, the remaining 14 wrecks were carrying mixed cargoes of goods, some of which had been transhipped in another location. These mixed province wrecks should be regarded as the movement of products from emporia, not due to cabotage. Further research could focus on these individual cases and their circumstances. 


\section{Products}

The different products transported in the 77 exclusively Baetican shipwrecks show a variation of combinations (Figure 5). What clearly emerges from this graph is that oil is the most common product - transported both on its own and alongside other products - followed by fish sauce and metal. Then a series of combinations of the different products were identified. The cargoes are homogeneous in terms of province but heterogeneous in terms of products and this also illustrates the habit of storing products in a harbour before loading them onto a ship. As mentioned before, even the ship with the most heterogeneous cargo would have been loaded at a single harbour, as having to adjust the balance of the ship every time a new item was loaded was definitely not worth the time, money, and effort.

\section{Brief assessment of three case studies: Sud Lavezzi 2, Albufereta, and Bou Ferrer}

Three case studies can be seen as representative of different models of Baetican cargoes. These case studies were chosen because they were well-published, permitting a detailed study of the wrecks and their cargoes.

The first wreck is the Sud Lavezzi 2, an early imperial wreck sunk in the Strait of Bonifacio between AD 22 and AD 25 (Liou and Domergue, 1990, p. 94). The cargo was composed of a series of different products all originally from Baetica, including Dressel 20, Haltern 70, Dressel 28, Dressel 8, Dressel 9, Dressel 7-11, and Pompeii VII amphorae carrying oil, wine, and fish sauce, along with copper and lead ingots (Liou and Domergue, 1990). The presence of stamps on the ingots stands out, as they name several individuals who were in charge of the loading of the vessel. Liou and Domergue hypothesised that this was a private shipment made by a group of individuals who consolidated their cargo onto a single vessel. Furthermore, one of the names is also stamped on the lead anchor found in the wreck, suggesting he may have been the owner of the vessel. The same loading pattern has been hypothesized for other wrecks from Baetica: for example, Port-Vendres II, Gandolfo, Cala Rossano (Arata, 1994; Colls et al., 1977; Liou and Rodríguez Almeida, 2000), which all present the merchandize of different individuals. Sharing a vessel between several merchants would have also allowed to split one's cargo between different ships, thus spreading the risk of a cargo sinking and losing all the products at once.

The second wreck is the Albufereta, dated between AD 50 and 70, which sank off the coast of Alicante. This was a smaller vessel loaded with three types of Dressel 20 amphorae and round copper ingots (Izquierdo et al., 2007). This wreck, due to its construction, size, and cargo, is thought to have been en route towards southern France (de Juan Fuertes, 2009), possibly as part of a convoy of small vessels that were travelling together, as hinted at by the nearby discovery of other wrecks with similar cargoes, such as the Portixol, Cap Prim, Ciutadella and Punta Nati wrecks (de Juan Fuertes, 2017). 
The last wreck to be considered is the Bou Ferrer, an exceptionally-well preserved wreck dated between AD 50 and 100, which, like the previous wrecks, sank off the coast of Alicante while carrying Dressel 7-11 amphorae and lead ingots (de Juan et al., 2014). However, this wreck was not going toward southern France but rather towards Italy, more specifically towards Rome, as indicated by the imperial stamps on the lead ingots, which indicate that they were owned by the imperial government. I In addition, the keelson appears to have been shaped especially to support the lead ingots (de Juan $e t$ al., 2014). This suggests a specialised vessel built to carry this type of cargo repeatedly on a particular route.

\section{Conclusion}

The data from the shipwrecks show different mechanisms through which cargoes were assembled and products were transported. We see a decline in the number of shipwrecks in the second century AD that is not reflected in terrestrial evidence. This difference could be a result of advanced harbour structures, lighthouses, sturdier vessels or better sailing capacities. Most of our Baetican shipwrecks (77 of the 91 wrecks) carried exclusively Baetican products, and represent the first major journey of these products, which were traveling from Baetica towards a specific destination. The cargoes composed of products of mixed provinces are much less frequent and represent individual cases that were the results of a single systematic loading. Turning to the exclusively Baetican cargo shipwrecks, we have seen that the main product transported on its own was oil, followed by fish sauce. The rest of the vessels carried a variety of products inside the hull. Even heterogeneous cargoes were the result of planned and organised trade, requiring in-depth knowledge of the market; they were not due to casual exchanges. Metal ingots, which have a high weight-to-volume ratio, were placed in the bottom of the hull to reinforce stability. Because of their weight, they needed to be combined with bulkier products such as amphorae, thus making the pair a suitable combination for a cargo. In addition, it would not be surprising if most of these vessels were carrying some perishable material, added as the last layer of their cargo.

The three case studies represent three different cargo compositions: one extremely heterogeneous cargo that seems to have been assembled by several different mercatores, a second representing a smaller vessel directed towards the French coast and loaded with oil and copper, and a third representing an imperially-owned cargo destined to Rome.

To conclude, this study highlights trends and peculiarities in the export economy of Roman Baetica over the first three centuries AD. It is clear that the products of the region were highly prized across the Roman West, and that these products moved through a variety of commercial networks that are most evident in heterogeneous cargo organisations. This province-specific investigation is naturally 
limited by the available evidence, but certainly highlights the complexity of the early imperial economy.

\section{Reference list}

Arata, F.P., 1994, Un relitto da Cala Rossano (Ventotene). Tituli picti su anfore e bollo su lingotti di stagno, in Epigrafia della produzione e della distribuzione. Actes de la VIIe Rencontre franco-italienne sur l'épigraphie du monde romain, Rome 5 - 6 juin 1992, 477-496. Rome.

Beltrame, C., 2002, Vita di bordo in età romana. Rome.

Blackman, D., 2008, Roman shipsheds, in R.L. Hohlfelder (ed.), The maritime world of ancient Rome : proceedings of "The Maritime World of Ancient Rome": Conference held at the American Academy in Rome, 27-29 March 2003, 23-36. Ann Arbor.

Blázquez Martínez, J.M. and Rodríguez, J.R., 2001, Estudios sobre el Monte Testaccio (Roma) II. Barcelona

Bombico, S., 2016, Lusitanian Amphorae on Western Mediterranean Shipwrecks: Fragments of Economic History, in Pinto, I.V., de Almeida, R. and Martin, A. (eds), Lusitanian amphorae : production and distribution: published on the occasion of the 30th Congress of the Rei Cretariae Romanae Fautores (Lisbon, 2016), 445-460. Oxford.

Bargagliotti, S., 2000, Il relitto dell'Ardenza (Livorno) : un carico di anfore betiche naufragato intorno alla metá del I sec. d.C., in Congreso Internacional Ex Baetica Amphorae. Conservas, Aceite y Vino de la Bética en el Imperio Romano (Ecija y Sevilla, 17 al 20 de Diciembre de 1998), 1111-1119. Ecija.

Carreras, C. and Funari, P.P.A., 2000, Estado y mercado en el abastecimiento de bienes de consumo en el Imperio Romano: un estudio de caso de la distribucion de aceite espanol en Britannia. História Econômica \& História de Empresas 3, 105-21.

Carreras, C. and Martin, A., 2013, Los naufragios de ánforas Haltern 70, in H. Granja, R.M.L. de Sousa Morais, Á.M. Cerdán (eds), O Irado Mar Atlântico. O Naufragio Bético de Esposende (Norte de Portugal), 283-308. Braga.

Colls, D., Étienne, R., Lequément, R., Liou, B. and Mayet, F., 1977, L'épave Port-Vendres II et le commerce de la Bétique à l'époque de Claude. Archaeonautica 1, 3-145.

Jones, H. L., Sitlington Sterrett, J. R. (trans), 1917, The Geography of Strabo, London.

de Juan Fuertes, C., 2009, La bahía de l'Albufereta (Alicante). Una" statio" náutica en el levante peninsular. Saguntum 41, 129-148.

de Juan Fuertes, C., 2017, Interpretando el pecio" Albufereta I", a partir de su arquitectura naval, in Carta Arqueológica Subacuática de Alicante I: Fondeadero de Lucentum (Bahía de l'albufereta, Alicante), Siglos V a.C.-X d.C., 115-125. Alicante.

de Juan Fuertes, C., Geli, R., Cibecchini, F., Mauri, G. and Vivar, G., forthcoming, Els derelictes Bou Ferrer i Illes Formigues II, dos jaciments extraordinaris per comprendre el comerç naval de la Bètica al periode juliclaudi. 
de Juan Fuertes, C., Cibecchini, F. and Miralles, J.S., 2014, El pecio Bou Ferrer (La Vila Joiosa, Alicante). Nuevos datos sobre su cargamento y primeras evidencias de la arquitectura naval, in Arqueología subacuática española : actas del I Congreso de Arqueología Náutica y Subacuática Española (Cartagena, 14, 15 y 16 de Marzo de 2013), 133-149. Madrid.

Dressel, H., 1878, Ricerche sul monte Testaccio, 118-192. Rome.

Etienne, R. and Mayet, F., 2000, Trois clés pour l'économie de l'Hispanie romaine. 1, Le vin hispanique. Paris.

Etienne, R. and Mayet, F., 2002, Trois clés pour l'économie de l'Hispanie romaine. 2, Salaisons et sauces de poisson hispaniques. Paris.

Etienne, R. and Mayet, F., 2004, Trois clés pour l'économie de 1'Hispanie romaine. 3, L'huile hispanique. Paris.

Harris, W.V., Iara, K. and Arnaud, P. (eds), 2011, Maritime technology in the ancient economy: shipdesign and navigation. Portsmouth, R.I.

Izquierdo, A.F., Millet, P.B. and Martin, A.A., 2007, El pecio romano de la Albufereta (Alicante): un documento de época pre-flavia, in J. Pérez Ballester and G. Pascual Berlanga (eds), Comercio, redistribución y fondeaderos : la navegación a vela en el Mediterráneo (Actas, V Jornadas internacionales de arqueología subacuática, Gandía (Valencia) 2006), 231-246. Gandía.

Lagóstena Barrios, L.G., 2009, Productos hispanos en los mercados de Roma: en torno al consumo de aceites y salazones de" Baetica" en el Alto Imperio, in J.A. Pintado (ed.), Hispaniae: Las Provincias Hispanas En El Mundo Romano, 293-308. Tarragona.

Liou, B., 1990, Le commerce de la Bétique au Ier siècle de notre ère : Notes sur l'épave Lavezzi 1 (Bonifacio, Corse du Sud). Archaeonautica 10, 125-155.

Liou, B., 2000, Las ánforas béticas en el mar, in Congreso Internacional Ex Baetica Amphorae. Conservas, Aceite y Vino de la Bética en el Imperio Romano (Ecija y Sevilla, 17 al 20 de Diciembre de 1998), 1061-1110. Ecija.

Liou, B. and Domergue, C., 1990, Le commerce de la Bétique au Ier siècle de notre ère. L'épave SudLavezzi 2 (Bonifacio, Corse du Sud). Archaeonautica 10, 11-123.

Liou, B. and Rodríguez Almeida, E., 2000, Les inscriptions peintes des amphores du Pecio Gandolfo (Almería). Mélanges de l'école française de Rome. Antiquité 112, 7-25.

Mendoza, E.C., 2016, La isla de Mallorca (Baleares) dentro de los circuitos comerciales de la Antiguiedad, in Actas del V Congreso Internacional de Arqueología Subacuática (IKUWA V), 574 589. Cartagena.

Nieto, F.J., 1997, Le commerce de cabotage et de redistribution, in P.A. Gianfrotta, P. Pomey and F.J. Nieto (ed.), La Navigation dans l'Antiquité, 146-159. Aix-en-Provence.

Nieto, F.J., 1986, El pecio Culip IV: observaciones sobre la organización de los talleres de Terra sigillata de La Graufesenque. Archaeonautica 6, 81-119.

Oleson, J., Brandon, C. and Hohlfelder, R., 2011, Technology, innovation, and trade: research into the engineering characteristics of Roman maritime concrete, in D. Robinson and A. Wilson (eds), Maritime Archaeology and Ancient Trade in the Mediterranean, 107-119. Oxford. 
Parker, A.J., 1992, Ancient shipwrecks of the Mediterranean \& the Roman provinces. Oxford.

Pinedo Reyes, J. and Alonso Campoy, D., 2004, El yacimiento submarino de la Isla de Escombreras, in M. Lechuga Galindo and F.J. Nieto, Scombraria: La Historia Oculta Bajo El Mar: Arqueología Submarina En Escombreras (Cartagena), 128-151. Murcia.

Pomey, P., Long, L. and L'Hour, M., 1992, Recherches sous-marines, in Gallia informations. L'archéologie des régions, 1-85. Paris.

Remesal Rodríguez, J., 2002, Baetica and Germania. Notes on the concept of "provincial interdependence" in the Roman Empire, in P. Erdkamp (ed.), The Roman Army and the Economy, 293308. Amsterdam.

Remesal Rodríguez, J., 2010, De Baetica a Germania, consideraciones sobre la ruta y el comercio atlántico en el Imperio Romano, in F. Marco Simón (ed.), Viajeros, Peregrinos y Aventureros En El Mundo Antiguo, 147-160. Barcelona.

Rice, C., 2016, Shipwreck cargoes in the western Mediterranean and the organization of Roman maritime trade. Journal of Roman Archaeology 29, 165-192.

Rico, C., Domergue, C., Rauzier, M., Klein, S., Lahaye, Y., Brey, G. and Von Kaenel, H.-M, 2005, La provenance des lingots de cuivre romains de Maguelone (Hérault, France). Étude archéologique et archéométrique. Revue archéologique de Narbonnaise 38, 459-472.

Robinson, D., Rice, C., and Schörle, K., forthcoming Ship Losses and the Growth of Roman Harbour Infrastructure. Journal of Maritime Archaeology.

Schörle, K., 2011, Constructing Port Hierarchies: harbours of the central Tyrrhenian coast, in A. Wilson and D. Robinson (eds), Maritime Archaeology and Ancient Trade in the Mediterranean, 93106. Oxford.

Strauss, J., 2013, Shipwrecks Database. Version 1.0. Accessed (18/07/2020): oxrep.classics. ox.ac.uk/databases/shipwrecks_database.

Tchernia, A. 1969, Les fouilles sous-marines de Planier (Bouches-du-Rhône). Comptes rendus des séances - Académie des inscriptions 1969, 292-309.

Wilson, A., 2009, Approaches to quantifying Roman trade, in A. Bowman and A.I. Wilson (eds), Quantifying the Roman Economy - Methods and Problems, 213-49. Oxford.

Wilson, A., 2011, Maritime archaeology and the ancient economy, in D. Robinson and A. Wilson (eds), Maritime Archaeology and Ancient Trade in the Mediterranean, 1-11. Oxford. 


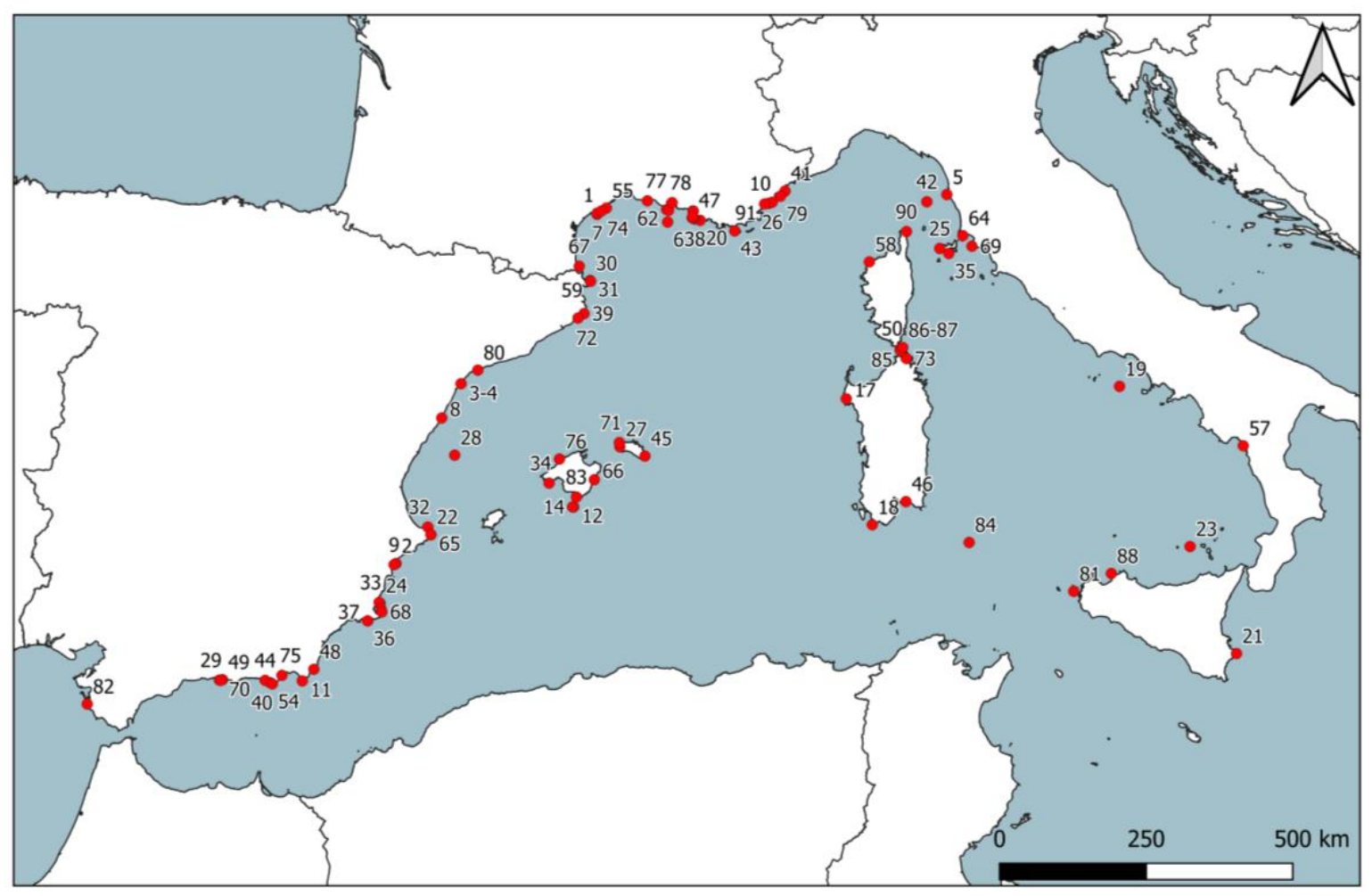

Figure 1: Location of the wrecks listed in Table 1 (author: Stella Rendina).

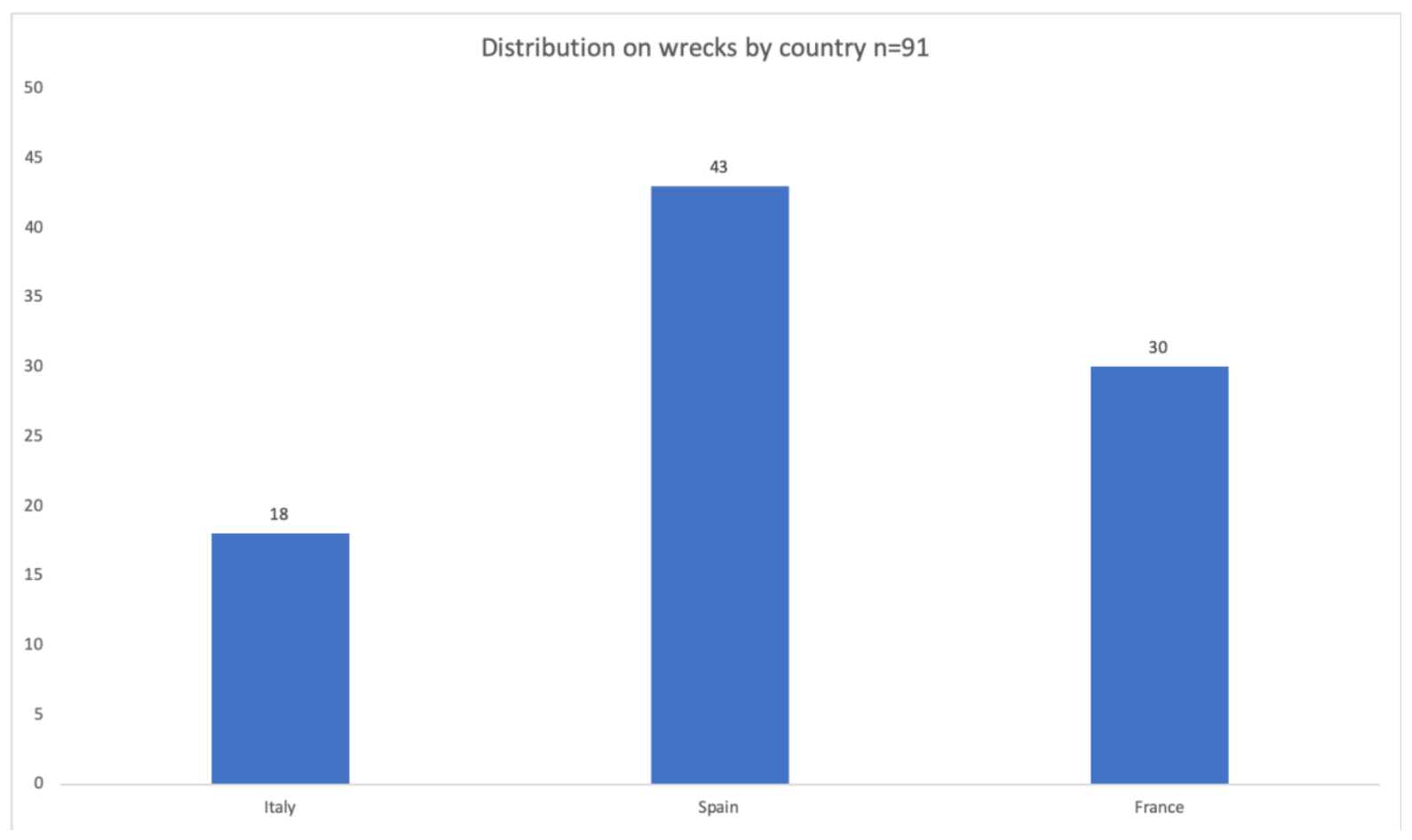

Figure 2: Location of wrecks by country, n=91 (author: Stella Rendina). 


\section{Shipwrecks by date $n=91$}

40

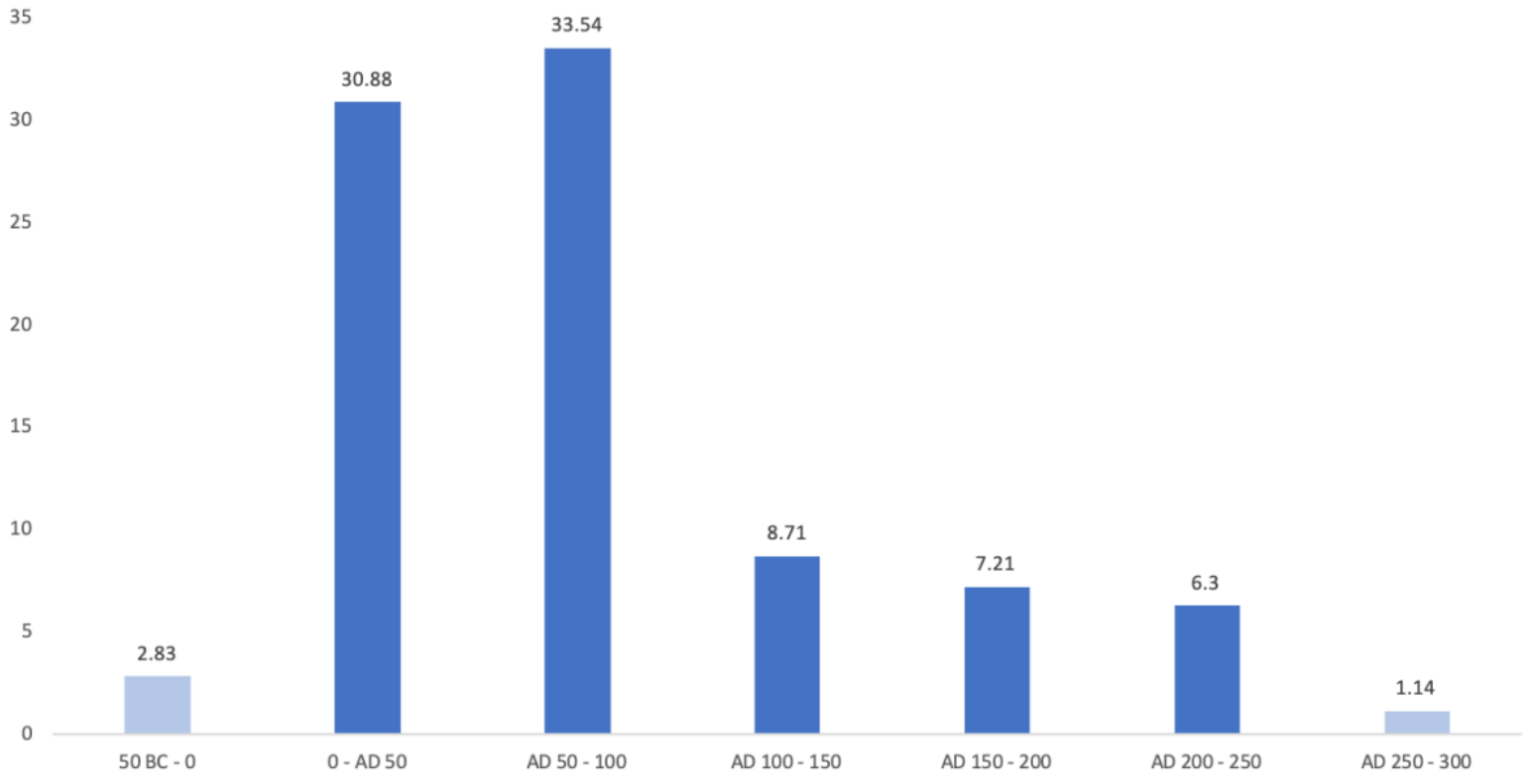

Figure 3: Date of the wrecks, n=91 (author: Stella Rendina).

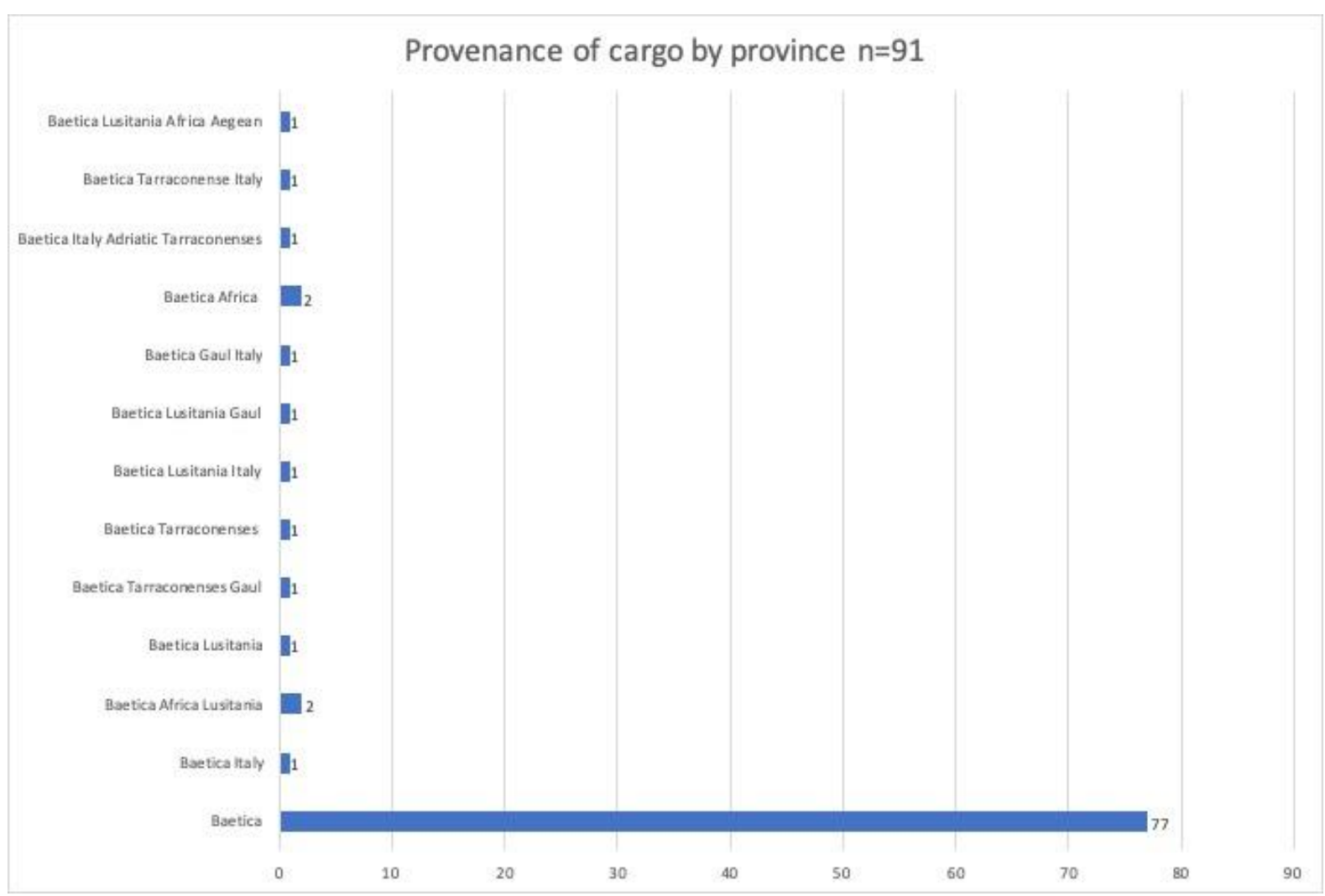

Figure 4: Province from which the cargo originated, n=91 (author: Stella Rendina). 


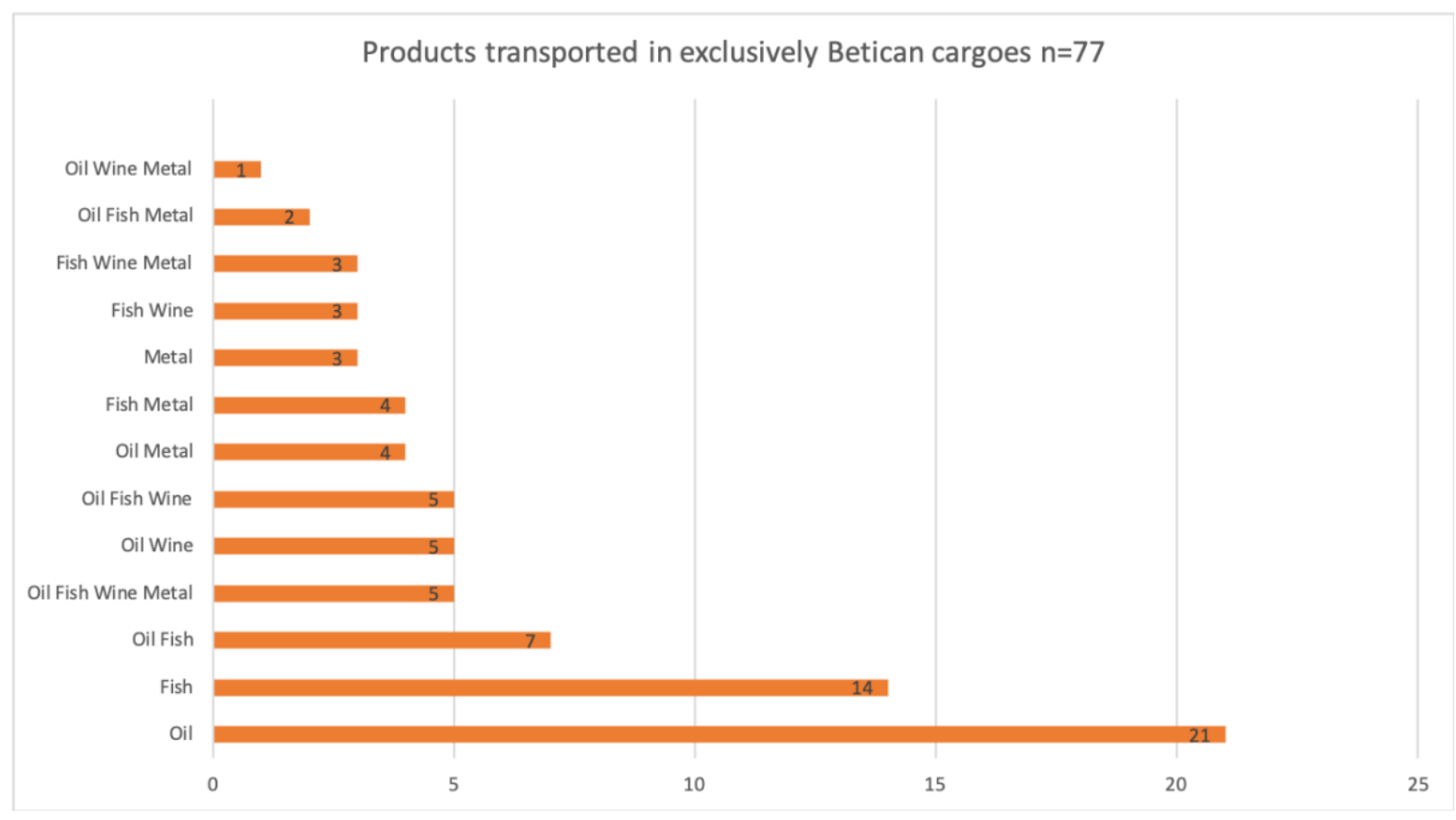

Figure 5: Combination of products transported in exclusively Baetican shipwrecks, n=77 (author: Stella Rendina).

Table 1: Shipwrecks with Baetican cargo found in the Western Mediterranean.

\begin{tabular}{|c|c|c|c|c|c|}
\hline $\mathrm{N}_{\mathrm{o}}$ & Name & Date & Material & Country & Bibliography \\
\hline 1 & Agde E & $\begin{array}{l}\text { End } 1 \text { st } \\
\text { century AD }- \\
\text { Beginning 2nd } \\
\text { century AD }\end{array}$ & Dressel 20 & France & Parker 1992, 12 \\
\hline 2 & Albufereta & AD $50-70$ & $\begin{array}{l}\text { Dressel } 20 \\
\text { Haltern } 70 \\
\text { Copper ingots }\end{array}$ & Spain & $\begin{array}{l}\text { de Juan Fuertes } \\
\text { 2009; Carreras and } \\
\text { Martin } 2013\end{array}$ \\
\hline 3 & $\begin{array}{l}\text { Ametlla del } \\
\text { Mar A }\end{array}$ & AD $25-75$ & $\begin{array}{l}\text { Dressel } 12 \\
\text { Dressel 2-4? }\end{array}$ & Spain & Parker 1992, 36 \\
\hline 4 & $\begin{array}{l}\text { Ametlla del } \\
\text { Mar C }\end{array}$ & $\begin{array}{l}1_{\text {st }}-3_{\mathrm{rd}} \\
\text { century } \mathrm{AD}\end{array}$ & Dressel 20 & Spain & Parker 1992, 38 \\
\hline 5 & Ardenza & AD $25-75$ & $\begin{array}{l}\text { Haltern } 70 \\
\text { Beltran IIA } \\
\text { Dressel } 12 \\
\text { Dressel 7-11 }\end{array}$ & Italy & $\begin{array}{l}\text { Parker 1992, 51; } \\
\text { Bargagliotti 2000 }\end{array}$ \\
\hline
\end{tabular}




\begin{tabular}{|c|c|c|c|c|c|}
\hline 6 & Arles IV & $\mathrm{AD} 25-40$ & $\begin{array}{l}\text { Dressel } 20 \\
\text { Dressel 7-11 } \\
\text { Dressel } 12 \\
\text { Dressel } 28 \\
\text { Haltern } 70 \\
\text { PE 25 } \\
\text { Ceramics } \\
\text { Copper ingots }\end{array}$ & France & $\begin{array}{l}\text { Pomey et al. 1992; } \\
\text { Carreras and Martin } \\
2013\end{array}$ \\
\hline 7 & $\begin{array}{ll}\text { Baie } & \text { de } \\
\text { l'Amitié }\end{array}$ & AD $50-100$ & $\begin{array}{l}98 \text { Lead ingots } \\
\text { Dressel } 20\end{array}$ & France & Parker 1992, 80 \\
\hline 8 & Benicarlo & AD 50-100 & $\begin{array}{l}1 \text { Dressel } 20 \\
2 \text { Dressel 2-4 } \\
\text { Haltern } 70\end{array}$ & Spain & Parker 1992, 99 \\
\hline 9 & Bou Ferrer & AD $50-100$ & $\begin{array}{l}\text { Dressel 7-11 } \\
\text { Lead ingots }\end{array}$ & Spain & $\begin{array}{l}\text { De Juan Fuertes } \\
2009\end{array}$ \\
\hline 10 & Boulouris & $\begin{array}{l}\text { Beginning 3rd } \\
\text { century AD }\end{array}$ & Dressel 20 & France & Parker 1992, 110 \\
\hline 11 & Cabo de Gata & AD $70-100$ & Dressel 20 & Spain & Liou 2000 \\
\hline 12 & Cabrera III & AD 257 & $\begin{array}{l}\text { Dressel } 20 \\
\text { Dressel 23C } \\
\text { Africana IIB and IIC } \\
\text { Almagro 50 } \\
\text { Almagro 51C } \\
\text { Beltran IIB } \\
\text { Beltran 72 } \\
\text { Coins }\end{array}$ & Spain & Parker 1992, 125 \\
\hline
\end{tabular}




\begin{tabular}{|c|c|c|c|c|c|}
\hline 13 & Cabrera IV & $\begin{array}{ll} & \text { st } \\
\text { AD } & \end{array}$ & $\begin{array}{l}\text { Dressel 7-11 } \\
\text { Oberdan } 80 \\
\text { Haltern } 70 \\
\text { Dressel 2-4 } \\
\text { Lead ingots } \\
\text { Lead anchors }\end{array}$ & Spain & Parker 1992, 126 \\
\hline 14 & Cabrera V & $\begin{array}{l}\text { End } \quad 1 \text { st } \\
\text { century AD - } \\
\text { beginning 2nd } \\
\text { century AD }\end{array}$ & $\begin{array}{l}\text { Dressel } 7 \\
\text { Dressel } 10 \\
\text { Dressel } 12 \\
\text { Dressel } 20 \text { Arcaicas } \\
\text { Haltern } 70 \\
\text { Lead ingots }\end{array}$ & Spain & $\begin{array}{l}\text { Parker 1992, } 127 \\
\text { Colom Mendoza } \\
2013\end{array}$ \\
\hline 15 & Cabrera VI & $\mathrm{AD} 40-70$ & $\begin{array}{l}\text { Dressel 7-11 } \\
1 \text { Dressel } 8 \\
1 \text { Dressel } 9 \\
\text { Copper ingots } \\
\text { Tin round ingots }\end{array}$ & Spain & $\begin{array}{ll}\text { Colom } & \text { Mendoza } \\
2013 & \end{array}$ \\
\hline 16 & Cabrera VIII & $\begin{array}{l}\text { End } \quad 1_{\text {st }} \\
\text { century BC }- \\
\text { beginning } 2 \text { nd } \\
\text { century AD }\end{array}$ & $\begin{array}{l}\text { Haltern } 70 \\
\text { Dressel } 80 \\
\text { Copper ingots }\end{array}$ & Spain & $\begin{array}{ll}\text { Colom } & \text { Mendoza } \\
2013 & \end{array}$ \\
\hline 17 & $\begin{array}{l}\text { Cala del Falco } \\
1\end{array}$ & AD 200-300 & Dressel 20 & Italy & Parker 1992 \\
\hline 18 & Cala piombo & c. $\mathrm{AD} 40$ & $\begin{array}{l}\text { Dressel } 20 \\
\text { Dressel } 8\end{array}$ & Italy & Liou 2000 \\
\hline 19 & Cala Rossano & AD $30-60$ & $\begin{array}{l}\text { Dressel } 8 \\
\text { Dressel } 9 \\
\text { Dressel 7-11 } \\
\text { Tin ingots }\end{array}$ & Italy & $\begin{array}{l}\text { Parker 1992, 153; } \\
\text { Beltrame 2002 }\end{array}$ \\
\hline 20 & $\begin{array}{l}\text { Calanque } \\
\text { Devenson } 1\end{array}$ & $\begin{array}{ll}1_{\text {st }} & \text { century } \\
\text { AD } & \end{array}$ & Dressel 20 & France & Strauss 2013 \\
\hline
\end{tabular}




\begin{tabular}{|c|c|c|c|c|c|}
\hline 21 & Cap Ognina & $\mathrm{AD} 215-230$ & $\begin{array}{l}\text { Africana I } \\
\text { Dressel } 20 \\
\text { Almagro } 50 \\
\text { Kapitän I and II } \\
\text { coins }\end{array}$ & Italy & $\begin{array}{l}\text { Étienne and Mayet } \\
2002\end{array}$ \\
\hline 22 & Cap prim & $\begin{array}{l}1_{\text {st }} \text { century } \\
\mathrm{AD}(?)\end{array}$ & $\begin{array}{l}\text { Dressel } 20 \\
\text { Copper ingots }\end{array}$ & Spain & $\begin{array}{l}\text { De Juan Fuertes } \\
2009\end{array}$ \\
\hline $\mathrm{d} 23$ & $\begin{array}{l}\text { Capo } \\
\text { Graziano C }\end{array}$ & $\begin{array}{l}\text { Beginning } 1_{\text {st }} \\
\text { century AD }\end{array}$ & $\begin{array}{l}\text { Dressel } 20 \text { archaic } \\
\text { Dressel } 7 \\
\text { Haltren } 70\end{array}$ & Italy & Parker 1992, 235 \\
\hline 24 & Castillo & $\begin{array}{l}\text { 2nd century } \\
\mathrm{AD}\end{array}$ & Beltrán IIB & Spain & Parker 1992, 279 \\
\hline 25 & Chiessi & AD $60-85$ & $\begin{array}{l}\text { Beltran IIA } \\
\text { Beltran IIB } \\
\text { Haltern } 70 \\
\text { Dressel } 20 \\
\text { Ingots } \\
\text { Terra sigillata }\end{array}$ & Italy & Parker 1992, 301 \\
\hline 26 & Chretienne B & AD 50-150 & Beltrán IIB & France & Parker 1992, 303 \\
\hline 27 & Ciudatella & $\begin{array}{ll} & \text { st } \\
\text { AD } & \end{array}$ & Dressel 20 & Spain & $\begin{array}{l}\text { De Juan Fuertes } \\
2009\end{array}$ \\
\hline 28 & Columbretes & $\begin{array}{l}25 \mathrm{BC}-\mathrm{AD} \\
75\end{array}$ & Dressel 7-11 & Spain & Parker 1992, 332 \\
\hline 29 & $\begin{array}{ll}\text { Cueva } & \text { del } \\
\text { Jarro B } & \end{array}$ & $\begin{array}{l}\text { End } 1_{\text {st }} \\
\text { century AD }\end{array}$ & $\begin{array}{l}\text { Dressel } 20 \\
\text { Beltran IIB }\end{array}$ & Spain & Parker 1992344 \\
\hline 30 & Culip 4 & $\mathrm{AD} 70-80$ & $\begin{array}{l}\text { Dressel } 20 \\
\text { Ceramic from La } \\
\text { Graufesenque } \\
\text { Italian lamps }\end{array}$ & Spain & $\begin{array}{l}\text { Nieto 1986; Parker } \\
\text { 1992, } 347\end{array}$ \\
\hline 31 & Culip 7 & $\mathrm{AD} 70-80$ & $\begin{array}{l}\text { Haltern } 70 \\
\text { Dressel } 20 \\
\text { Pascula } 1\end{array}$ & Spain & $\begin{array}{l}\text { Carreras and Martin } \\
2013\end{array}$ \\
\hline
\end{tabular}




\begin{tabular}{|c|c|c|c|c|c|}
\hline 32 & Denia & AD $150-225$ & Dressel 20 & Spain & Parker 1992, 358 \\
\hline 33 & $\begin{array}{ll}\text { Dunas del } \\
\text { Pinatar }\end{array}$ & $\mathrm{AD} 1-50$ & Dressel 20 & Spain & Parker 1992, 380 \\
\hline 34 & El Toro & $\mathrm{AD} 25-40$ & $\begin{array}{l}\text { Dressel } 9 \\
\text { Dressel } 7 \\
\text { Dressel } 10 \\
\text { Dressel } 8\end{array}$ & Spain & Parker 1992,1150 \\
\hline 35 & Elba & AD $25-75$ & $\begin{array}{l}\text { Dressel } 10 \\
\text { Haltern } 70 \\
\text { Dressel 7-11 } \\
\text { Pompeii VII }\end{array}$ & Italy & $\begin{array}{l}\text { Carreras and Martin } \\
2013\end{array}$ \\
\hline 36 & Escombrera 3 & $\begin{array}{l}\text { Beginning } 1_{\text {st }} \\
\text { century AD }\end{array}$ & $\begin{array}{l}\text { Haltern } 70 \\
\text { Lomba do Canho } 67 \\
\text { Pascual } 1 \\
\text { Dressel } \\
\text { Tarraconensis } \\
\text { Dressel } \\
\text { Campania } \\
\text { Adriatic Dressel } 6\end{array}$ & Spain & $\begin{array}{l}\text { Alonso and Pinedo } \\
2004\end{array}$ \\
\hline 37 & Escombrera 4 & AD $50-100$ & $\begin{array}{l}\text { Haltern } 70 \\
\text { Dressel } 8 \\
\text { Dressel } 9 \\
\text { Dressel } 14 \\
\text { Beltran IIB } \\
\text { Dressel } 20\end{array}$ & Spain & $\begin{array}{l}\text { Alonso and Pinedo } \\
2004\end{array}$ \\
\hline 38 & $\begin{array}{ll}\text { Esteu } & \text { don } \\
\text { Mieu } 2 & \end{array}$ & AD $69-96$ & $\begin{array}{l}\text { Dressel } 20 \\
\text { Beltran } \\
\text { (Fragments) }\end{array}$ & France & Liou 2000 \\
\hline 39 & Formigues & $\begin{array}{l}\text { End } 1_{\text {st }} \\
\text { century AD }\end{array}$ & Dressel 7-11 & Spain & $\begin{array}{l}\text { De Juan Fuertes et } \\
\text { al. forthcoming }\end{array}$ \\
\hline
\end{tabular}




\begin{tabular}{|c|c|c|c|c|c|}
\hline 40 & Gandolfo & AD $90-110$ & $\begin{array}{l}\text { Dressel } 14 \\
\text { Dressel } 17 \\
\text { Beltran IIA }\end{array}$ & Spain & Parker 1992, 435 \\
\hline 41 & Garoupe C & AD $150-200$ & Dressel 20 & France & $\begin{array}{l}\text { Tchernia 1969; } \\
\text { Parker 1992, } 438\end{array}$ \\
\hline 42 & Gorgona & $\begin{array}{ll}1_{\text {st }} & \text { century } \\
\mathrm{AD} & \end{array}$ & $\begin{array}{l}\text { Dressel 7-11 } \\
\text { Beltran IIA }\end{array}$ & Italy & Parker 1992, 461 \\
\hline 43 & $\begin{array}{l}\text { Grand Ribaud } \\
2\end{array}$ & $\begin{array}{l}\text { Flavian (AD } \\
69-96)\end{array}$ & Dressel 20 & France & Liou 2000 \\
\hline 44 & $\begin{array}{l}\text { Guardias } \\
\text { Viejas }\end{array}$ & $\begin{array}{l}\text { End } 1_{\text {st }} \\
\text { century AD }\end{array}$ & $\begin{array}{l}\text { Dressel 7-11 } \\
\text { Dressel } 14 \\
\text { Dressel } 20\end{array}$ & Spain & Parker 1992, 488 \\
\hline 45 & Illa de l'Aire & $\begin{array}{l}\text { Mid } 1_{\text {st }} \\
\text { century AD }\end{array}$ & $\begin{array}{l}\text { Dressel } 20 \\
\text { Dressel } 28 \\
\text { Dressel 7-11 } \\
\text { Beltran IIB } \\
\text { Haltern } 40\end{array}$ & Spain & $\begin{array}{l}\text { Carreras and Martin } \\
2013\end{array}$ \\
\hline 46 & Is Mortius & AD $33-55$ & $\begin{array}{l}\text { Haltern } 70 \\
\text { Dressel 1C } \\
\text { Camulodunum } 186 \\
\text { Dressel 7-11 }\end{array}$ & Italy & Parker 1992, 602 \\
\hline 47 & Jarre & $\mathrm{AD} 10-50$ & Dressel 20 & France & Parker 1992, 529 \\
\hline 48 & Las Negres & C. AD 50 & $\begin{array}{l}\text { Beltran IIB } \\
\text { Dressel } 20\end{array}$ & Spain & Parker 1992, 731 \\
\hline 49 & Las Puntas & AD $90-140$ & Dressel 20 & Spain & Parker 1992, 972 \\
\hline 50 & Lavezzi 1 & $\mathrm{AD} 25-50$ & $\begin{array}{l}\text { Dressel } 28 \\
\text { Dressel } 14 \\
\text { Dressel } 38 \\
\text { Haltern } 70\end{array}$ & France & Liou 1990 \\
\hline
\end{tabular}




\begin{tabular}{|c|c|c|c|c|c|}
\hline & & & $\begin{array}{l}\text { Dressel } 20 \\
\text { Dressel } \\
\text { Tarraconensis } \\
\text { Copper ingots } \\
\text { Lead ingots }\end{array}$ & & \\
\hline 51 & Lavezzi 2 & $\begin{array}{l}\text { Mid } 1_{\text {st }} \\
\text { century AD }\end{array}$ & $\begin{array}{l}\text { Dressel 7-11 } \\
\text { Dressel } 20\end{array}$ & France & Parker 1992, 585 \\
\hline 52 & Lavezzi 3 & AD $70-100$ & $\begin{array}{l}\text { Dressel } 14 \\
\text { Dressel } 17\end{array}$ & France & Parker 1992, 586 \\
\hline 53 & Los Espins & $\begin{array}{l}25 \mathrm{BC}-\mathrm{AD} \\
50\end{array}$ & Dressel 7-11 & Spain & Parker 1992, 390 \\
\hline 54 & Los Percheles & $\begin{array}{ll}\text { st } & \text { century } \\
\text { AD } & \end{array}$ & Dressel 7-11 & Spain & Parker 1992, 800 \\
\hline 55 & Maguelone & $\begin{array}{l}1_{\text {st }} \quad \text { century } \\
\text { BC }-\mathrm{AD} 96\end{array}$ & $\begin{array}{l}\text { Copper ingots } \\
\text { Lead ingots }\end{array}$ & France & Rico et al. 2005 \\
\hline 56 & Maire B & $\begin{array}{l}\text { Beginning 2nd } \\
\text { century AD }\end{array}$ & Dressel 20 & France & Parker 1992, 632 \\
\hline 57 & Maratea B & $\begin{array}{l}1 \text { st century } \\
\mathrm{AD}-3 \mathrm{rd} \\
\text { century } \mathrm{AD}\end{array}$ & Dressel 20 & Italy & Parker 1992, 648 \\
\hline 58 & Oscellucia & $\mathrm{AD} 20-50$ & Dressel 20 archaic & Italy & $\begin{array}{l}\text { Tchernia } 1969 ; \\
\text { Parker 1992, } 766\end{array}$ \\
\hline 59 & Piedra Negra & $\begin{array}{l}\text { End } \quad 1_{\text {st }} \\
\text { century AD - } \\
\text { beginning } 2 \text { nd } \\
\text { AD }\end{array}$ & Dressel 20 & Spain & Parker 1992, 814 \\
\hline 60 & Plainer 2 & c. $\mathrm{AD} 150$ & $\begin{array}{l}\text { Dressel } 20 \\
\text { Copper ingots }\end{array}$ & France & Parker 1992, 825 \\
\hline 61 & Plainer 4 & $\begin{array}{l}\text { End } 1_{\text {st }} \\
\text { century AD }\end{array}$ & $\begin{array}{l}\text { Beltran IIA and B } \\
\text { Dressel } 20 \\
\text { Copper ingots }\end{array}$ & France & $\begin{array}{l}\text { Carrasco and } \\
\text { Melendez } 2017\end{array}$ \\
\hline 62 & $\begin{array}{l}\text { Planes } \\
\text { d'Arles } 4\end{array}$ & AD $0-50$ & Dressel 20 & France & Liou 2000 \\
\hline
\end{tabular}




\begin{tabular}{|c|c|c|c|c|c|}
\hline & & & $\begin{array}{l}\text { Dressel 7, 8, 9, } 12 \\
\text { Haltern } 70 \\
\text { Dressel } 28 \\
\text { Copper ingots }\end{array}$ & & \\
\hline 63 & $\begin{array}{l}\text { Planes } \\
\text { d'Arles } 8\end{array}$ & $\begin{array}{l}30 \mathrm{BC}-\mathrm{AD} \\
20\end{array}$ & $\begin{array}{l}\text { Dressel } 9 \\
\text { Dressel } 12 \\
\text { Iron ingots }\end{array}$ & France & Liou 2000 \\
\hline 64 & Ponte d'Oro & $\begin{array}{l}\text { Mid } 1_{\text {st }} \\
\text { century AD }\end{array}$ & $\begin{array}{l}\text { Dressel 2-4 } \\
\text { Haltern 70 } \\
\text { Dressel 7-11 } \\
\text { Dressel } 8 \\
\text { Dressel } 20\end{array}$ & Italy & Parker 1992, 863 \\
\hline 65 & Portixol & Imperial & Dressel 20 & Spain & $\begin{array}{l}\text { De Juan Fuertes } \\
2009\end{array}$ \\
\hline 66 & Porto Cristo B & $\begin{array}{ll}1_{\text {st }} & \text { century } \\
\text { AD } & \end{array}$ & $\begin{array}{l}\text { Dressel } 20 \\
\text { Haltern } 70\end{array}$ & Spain & Parker 1992, 886 \\
\hline 67 & $\begin{array}{l}\text { Port-Vendres } \\
2\end{array}$ & $\mathrm{AD} 42-50$ & $\begin{array}{l}\text { Dressel } 20 \\
\text { Haltern } 70 \\
\text { Dressel } 28 \\
\text { Dressel 7-11 } \\
\text { Copper ingots } \\
\text { Lead ingots } \\
\text { Tin ingots }\end{array}$ & France & Parker 1992, 875 \\
\hline 68 & $\begin{array}{l}\text { Pudrimel } \\
\text { Norte }\end{array}$ & $\mathrm{AD} 50-150$ & Beltran IIB & Spain & Parker 1992, 909 \\
\hline 69 & Punta Ala A & c. $\mathrm{AD} 250$ & $\begin{array}{l}\text { Dressel } 20 \\
\text { Africana } 2 \text { B-D } \\
\text { Dolia fragments } \\
\text { Almagro } 51 \text { A-B } \\
\text { Almagro } 51 \mathrm{c} \\
\text { Beltran } 72\end{array}$ & Italy & Parker 1992, 912 \\
\hline
\end{tabular}




\begin{tabular}{|c|c|c|c|c|c|}
\hline & & & $\begin{array}{l}\text { Dressel } 20 \\
\text { Dressel } 23 \\
\text { ARS } \\
\text { Flat bottomed } \\
\text { container } \\
\text { Coins }\end{array}$ & & \\
\hline 70 & $\begin{array}{lll}\text { Punta de la } \\
\text { Mona }\end{array}$ & $\begin{array}{ll}\text { 2nd } & \text { century } \\
\text { AD } & \end{array}$ & 2 Dressel 20 & Spain & Parker 920 \\
\hline 71 & Punta Nati & Imperial & $\begin{array}{l}60 \text { round copper } \\
\text { ingots }\end{array}$ & Spain & $\begin{array}{ll}\text { De Juan } & \text { Fuertes } \\
2009 & \end{array}$ \\
\hline 72 & Punta prima & $\begin{array}{l}\text { End } 1 \text { st } \\
\text { century AD }\end{array}$ & Dressel 10 & Spain & Parker 1992, 956 \\
\hline 73 & $\begin{array}{l}\text { Punta } \\
\text { Sardinia A }\end{array}$ & $\begin{array}{l}\text { End } 1 \text { st } \\
\text { century AD - } \\
\text { beginning 2nd } \\
\text { century AD }\end{array}$ & $\begin{array}{l}\text { Dressel 14 Lusitania } \\
\text { Dressel } 7 \text {-11 } \\
\text { Dressel } 20 \\
\text { Dressel 2-4 Italian }\end{array}$ & Italy & $\begin{array}{l}\text { Parker 1992, 959; } \\
\text { Bombico 2016 }\end{array}$ \\
\hline 74 & $\begin{array}{l}\text { Riches Dunes/ } \\
\text { Marseillan- } \\
\text { Plage E }\end{array}$ & $\begin{array}{l}\text { Mid } 1_{\text {st }} \\
\text { century AD }\end{array}$ & $\begin{array}{l}\text { lead ingots } \\
\text { copper ingots } \\
\text { Dressel } 20\end{array}$ & France & Parker 1992, 667 \\
\hline 75 & $\begin{array}{l}\text { Roquetas del } \\
\text { Mar }\end{array}$ & $\begin{array}{l}1_{\text {st }}-2_{\text {nd }} \\
\text { century AD }\end{array}$ & $\begin{array}{l}1 \text { Dressel } 20 \text { archaic } \\
1 \text { Dressel } 8 \\
1 \text { Dressel } 1 \\
1 \text { Dressel } 14\end{array}$ & Spain & Parker 1992, 370 \\
\hline 76 & Sa Costera & Imperial & $\begin{array}{l}\text { Dressel } 20 \\
\text { Dressel } 12 \\
\text { Africana grande IIB } \\
\text { Copper ingots } \\
\text { circulares } \\
\text { Tin ingots }\end{array}$ & Spain & $\begin{array}{l}\text { Colom Mendoza } \\
2013\end{array}$ \\
\hline
\end{tabular}




\begin{tabular}{|c|c|c|c|c|c|}
\hline 77 & $\begin{array}{l}\text { Saintes- } \\
\text { Maries-de-la- } \\
\text { Mer } 2\end{array}$ & $\mathrm{AD} 1-25$ & $\begin{array}{l}\text { Haltern } 70 \\
\text { Dressel 2-4 } \\
\text { Dressel 20 } \\
\text { Dressel 2-4 de } \\
\text { Tarraconensis } \\
\text { Iron ingots from } \\
\text { Galia }\end{array}$ & France & Liou 2000 \\
\hline 78 & $\begin{array}{l}\text { Saint-Gervais } \\
3\end{array}$ & c. $\mathrm{AD} 150$ & $\begin{array}{l}\text { Dressel } 20 \\
\text { Beltran IIB } \\
\text { Gauloise } 4\end{array}$ & France & Parker 1992, 1002 \\
\hline 79 & Saint-Honorat & AD $50-100$ & Dressel 20 & France & Parker 1992,1003 \\
\hline 80 & Salou & $\mathrm{AD} 50-200$ & Dressel 20 & Spain & Parker 1992, 1018 \\
\hline 81 & San Nicola & $\begin{array}{l}\text { Beginning } 1_{\text {st }} \\
\text { century AD }\end{array}$ & $\begin{array}{l}\text { Dressel } 20 \\
\text { Dressel } 28\end{array}$ & Italy & Parker 1992, 1021 \\
\hline 82 & Sancti Petri & $\begin{array}{l}\text { End } 1_{\text {st }} \\
\text { century AD }\end{array}$ & $\begin{array}{l}\text { Copper and lead } \\
\text { ingots }\end{array}$ & Spain & Parker 1992, 1027 \\
\hline 83 & $\begin{array}{l}\text { Ses Salines/ } \\
\text { Santi Jordi }\end{array}$ & $\mathrm{AD} 70-80$ & $\begin{array}{l}\text { Dressel } 20 \\
\text { Dressel 7-11 } \\
\text { Beltran IIB } \\
\text { Lead ingots }\end{array}$ & Spain & $\begin{array}{l}\text { Parker 1992, 1017; } \\
\text { Mendoza 2013 }\end{array}$ \\
\hline 84 & Skerki Bank & $\begin{array}{l}\text { Mid } 1_{\text {st }} \\
\text { century AD }\end{array}$ & $\begin{array}{lr}\text { Dressel 7-11 } \\
\\
\text { Dressel } & 2-4 \\
\text { Tarraconensis } & \text { and } \\
\text { Italian } & \end{array}$ & Italy & $\begin{array}{l}\text { Étienne y Mayet } \\
2002\end{array}$ \\
\hline 85 & $\begin{array}{l}\text { Sud-Lavezzi } \\
\text { B (2) }\end{array}$ & $\mathrm{AD} 22-25$ & $\begin{array}{l}\text { Dressel } 28 \\
\text { Dressel } 20 \\
\text { Haltern } 70 \\
\text { Copper ingots Lead } \\
\text { ingots }\end{array}$ & France & $\begin{array}{l}\text { Liou and Domergue } \\
\text { 1990; Parker 1992, } \\
1118\end{array}$ \\
\hline 86 & $\begin{array}{l}\text { Sud-Perduto } \\
\text { A }\end{array}$ & $\begin{array}{l}25 \mathrm{BC}-\mathrm{AD} \\
25\end{array}$ & Dressel 12 & France & Parker 1992,1120 \\
\hline
\end{tabular}




\begin{tabular}{|c|c|c|c|c|c|}
\hline 87 & $\begin{array}{l}\text { Sud-Perduto } \\
\text { B }\end{array}$ & $\mathrm{AD} 1-5$ & $\begin{array}{l}\text { Dressel 7, 9, 10, } 12 \\
\text { Dressel } 20 \text { archaic } \\
\text { Lead ingots }\end{array}$ & France & Parker 1992, 1121 \\
\hline 88 & Terrasini A & $\mathrm{AD} 25-50$ & $\begin{array}{l}\text { Dressel } 8 \\
\text { Dressel } 9\end{array}$ & Italy & Parker 1992,1141 \\
\hline 89 & $\begin{array}{l}\text { Tiboulen } \mathrm{de} \\
\text { Maire } 1\end{array}$ & AD $130-150$ & $\begin{array}{l}\text { Dressel } 28 \\
\text { Gauloise } 4 \\
\text { Dressel 2-4 } \\
\text { Dressel } 14 \\
\text { Dressel } 20 \\
\text { Dressel 7-11 } \\
\text { Beltran IIA and IIB } \\
\text { Forlimpopoli } \\
\text { Africana }\end{array}$ & France & Parker 1992, 1148 \\
\hline 90 & $\begin{array}{ll}\text { Tour } & \text { Saint- } \\
\text { Marie } & \end{array}$ & $\mathrm{AD} 30-50$ & $\begin{array}{l}\text { Dressel 7-11 Dressel } \\
12 \\
\text { Beltran IIA } \\
\text { Haltern } 70\end{array}$ & France & $\begin{array}{l}\text { Tchernia } 1969 ; \\
\text { Parker 1992, } 1171\end{array}$ \\
\hline 91 & Villepey & $\mathrm{AD} 110-160$ & $\begin{array}{l}\text { Dressel } 20 \\
\text { Gauloise } 4\end{array}$ & France & Parker 1992, 1219 \\
\hline
\end{tabular}

